\title{
Of fear and fantasy, fact and fiction: Interrogating canonical Indian literary historiography towards comprehending partition of Bengal in post-Independence Indian (English) fictional space
}

\author{
Ashes Gupta \\ Professor, Dept. of English, Tripura University (A Central University), Suryamaninagar, Agartala, \\ West Tripura. ORCID: oooo-0oo2-5881-8468. Email: ashesgupta@tripurauniv.in
}

\begin{abstract}
A victim of the partition of Eastern India/undivided Bengal, a refugee is one who has ironically left behind the real but has carried on forever indelibly imprinted in memory that which is lost and remembered in superlatives, thus moving and simultaneously resisting to move. Remaining mentally anchored forever on 'Bengal's shore' and having been denied the moment of adequate articulation of the loss in factual terms partly due to immediate trauma and partly due to the inherent politics of the language of standard literary expression vis-à-vis spoken language (Bangla vs Bangal respectively) with its hierarchic positionings, as well as the politics of state policy that attributed partition of Western India primordial signification, the Bengali Hindu refugee migrating from erstwhile East Pakistan (and now Bangladesh) to India, has never 'really' spoken and this is the hypothesis of this argument. Thus, what is heard, being far removed from the historical moment of rupture that was partition and with the loss of that fateful generation is bound to be 'fiction' and not 'fact'. This paper proposes that since the refugee voice was denied adequate articulation of the 'facts' and the 'fears' resultant from partition in this part of Eastern India, that historical moment of perception and documentation has been irretrievably lost. Hence any attempt at documenting the same now shall obviously result in fictionalization of and fantasizing the loss as is evident in original and translational post-Independence Indian English Fiction -the moment of loss being the moment of fictional genesis. This paper also puts forward the necessity of identifying two specific periods beyond 'independence' whose axiomatic point would be the partition of Eastern India/ undivided Bengal viz. pre-partition and postpartition Indian Literature. The same shall apply to Indian English Literature both in original and translation.
\end{abstract}

Keywords: fear, fantasy, fact, fiction, partition, canonical historiography, refugee, independence, Indian English fictional space, inter-semiotic, translation.

Go where you will - I shall remain forever on Bengal's shore, Shall see jackfruit leaves dropping in the dawn's breeze, And the brown wings of shallik ${ }^{i}$ chill in the evening, Its yellow leg under the white, going down dancing.....

(Dasgupta and Bagchi, 2007)

These iconic lines from Rupasi Bangla by Jibanananda Das effectively encode the refugee psyche's attachment to the idea of Bengal (unpartitioned) both as a physical and psychic space that is indelible. A victim of the partition of Eastern India/undivided Bengal, a refugee is one who has ironically left behind the real, but has carried on forever indelibly imprinted in memory that which is lost forever, but remembered in superlatives, thus moving and simultaneously resisting to move.

(c) AesthetixMS 2020. This Open Access article is published under a Creative Commons Attribution Non-Commercial 4.0 International License (http://creativecommons.org/licenses/by-nc/4.o/), which permits non-commercial re-use, distribution, and reproduction in any medium, provided the original work is properly cited. For citation use the DOI. For commercial re-use, please contact editor@rupkatha.com. 
This peculiar paradoxicality of existence is also the cause of much trauma, the trauma that I am referring to here is not that of physical violence and atrocities inflicted on him alone, but more than that the trauma of being uprooted from 'your land' one fine morning due to a political decision taken by those whose lives remained unaffected by the futility of the same decision. The field of green corn swaying in the breeze ready to be harvested by someone else's sickle, your own home that suddenly becomes a house, your land of birth transformed to a land not for you from which you have to move to a land that has been decided upon to be yours, account for atrocities more severe. This paper strives to arrive at the hypothesis that these myriad traumas faced by the refugee, who is a victim of the partition of Eastern India, having been lost in the language politics (both translational and otherwise as discussed here), has perhaps been in Indian Fiction in general as well as in Indian English Fiction, both original and in translation.

In fact, the very scanty documentation of this trauma gets further problematised by the inherent politics of translation and language. It is pertinent here to comprehend that the Bengali language system as it is still used in West Bengal vis-à-vis other parts of the globe including Bangladesh, Tripura, Assam' Barak Valley etc (the so called 'Bengali diaspora'), incorporates dialectic variations of such magnitude that for convenience's sake, we generally acknowledge two different broad varieties of language- Bangla and Bangal, the language of West Bengal and East Bengal respectively, with further sub-dialectical variations. The pride of place that Kolkata in West Bengal has occupied historically, culturally and strategically (also economically since for a long time it had been the economic center of Eastern India), has priviledged Bangla as a language in both written and spoken forms. This has led to a certain hierarchic stratification making Bangla the established and standard mode of literary expression, whereas Bangal has remained a spoken language more or less. Consequently the refugees migrating to this side of the border as a result of partition, traumatised by fear and loss and speaking Bangal, were also at a loss of language largely, because their voices, if at all audible were actually allowed audibility and documentation in ecriture through translation in Bangla (the 'established standard of literary writing). Translation as a process entails a certain loss of culture and sensibility that is unavoidable since it begins by acknowledging the impossibility of translation itself leading inevitably to approximation. Thus, what was to be articulated by the refugee from erstwhile East Bengal naturalized in the phonetics, morphology, syntax and resultant semantics of connotation of Bangal, was translated and made available in a different language variety which automatically triggered lapses, silences, interpolations, appropriations and approximations, all in the process of documentation and translation.

Moreover, it is pertinent to theoretically comprehend that even the process of ideation to expression and utterance is an inter-semiotic translational ${ }^{\text {ii }}$ process entailing lapses, silences, interpolations, appropriations, exaggerations, and approximations. It has already been stated that the refugees on the eastern part of India tend to remember (atleast some of them including first generation refugees like my late grandmother) their homeland on the other side of the border in superlatives, which also is a fictionalization of fact.

The loss of the land after partition actually meant a disappearance of that ecological niche which was a combination of favorable factors such as food, shelter, temperate weather conditions, lesser number of competitors and so on that made the refugees viable in their land of origin; an overall design in nature that made life in the lost land idyllic. In comparison, everything in the land of refuge was dull and adulterated and that was true for even human relations on this side of the border. (Gupta, 54)

Therefore, what is received in such a translation (through habitual fictionalizing in superlatives, probably unique for refugees from East Bengal) is not 'fact', if 'fact' is to be understood by the 
Source Text (ST Proper) of refugee experience, but TT of refugee ideation and utterance (ideation and utterance/orality as texts) which is assumed to be $\mathbf{S T}$, where a certain fictionalization of fact takes place. Ideally if the refugee author would himself undertake the ecriture and documentation of this experience, ideation, expression triangulation in Bangal, that would have been Target Text 1 (TT 1). However, that has not happened, resulting in a lapse in literary historiography that has been further silenced by a wishful amnesia about partition in general in Eastern India. Hence, the Target Text 2 in Bangla (TT 2) which is the result of the translator's ventriloquism (Gupta, 2009) is theoretically nothing but fiction. Nilkantha Pakhir Khonje by Atin Bandopadhyay, Jalpaihati by Jibanananda Das, Bakulatala PL Camp by Narayan Gangopadhyay. Purba Paschim by Sunil Gangopadhyay etal. are cases in point, being instances of TT 2 in this formulation. What is ironic here is that the hierarchic positionings inherent in this system privileging Bangla over Bangal makes such translations within the system so naturalized and therefore legalized that it is not perceived as translation at all. The same fictionality is all the more reinforced and strengthened by a triple distanciation, through translation (now apparent) to Target Text 3 (TT 3 ) of Indian English fiction both in original and translation such as Dialectic by Selina Hussain trans. Barnita Bagchi, Biological by Narendranath Mitra trans. Tista Bagchi etal. A schematic representation of these theoretical positions is attempted below:

\section{TRANSLATION PROCESS IN ITS TOTALITY: A THEORETICAL POSSIBILITY.}

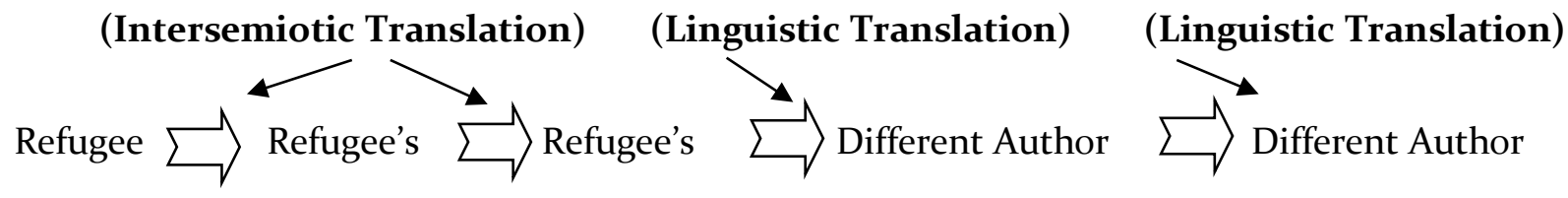
Experience
Ideation +
Ecriture/ Utterance
Text in Bangla
Text in

ST Proper Perception $\quad$ in Bangal (ST) $\quad$ (TT 2) Indian

$$
\text { (as Text) } \quad(\text { TT } 1 / S T \text { for TT } 2)
$$

in Bangal

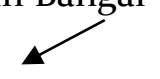

(TT assumed ST for TT 1)

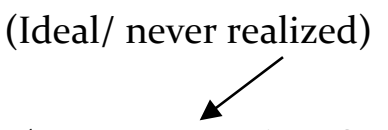

(TT 1 assumed ST for TT 2)
English (TT 3)

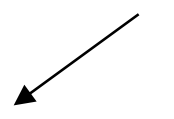
FACT
FICTION
FICTION
FICTION
FICTION

Therefore, theoretically this paper proposes to view only the Refugee experience as ST Proper i.e. the original/ proper Source Text (ST) and hence fact, whereas all other translational derivatives, intersemiotic and linguistic, as Target Texts and thus fictionalized. With the loss of the first generation of refugees, to which my late grandmother Hashibala Gupta belonged (Gupta 50-53), the ST of Refugee experience shall be (or already has been) irretrievably lost forever. This schema can be broken down into the following segments, each representing the Text- TranslationFact/Fiction paradigm: 
4 | Rupkatha Journal, Vol. 12, No. 4, 2020

1. Refugee experience as Source Text:

Refugee experience of partition

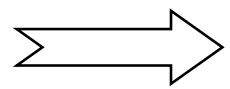

Refugee's ideation + perception

ST Proper FACT

in Bangal (TT) FICTION

2. Refugee as Author (INTERSEMIOTIC TRANSLATION):

TT assumed to be ST

TT 2

Ideation and perception in Bangal

(by the refugee) ～(ideally refugee as author)

FICTION

FICTION

3. Refugee utterance, different author: TRANSLATION within Bengali Language system:

TT 1 (assumed to be ST)

TT 2

\author{
Ideation and perception in Bangal $\sum$ Ecriture and documentation in Bangla \\ + expression/ utterance in Bangal as text \\ (incl. of orality as text by the refugee) Different author \\ FICTION \\ FICTION
}

4.Bangla to English:TRANSLATION from Bangla to English (the Indian English venture):

TT 2 assumed to be ST

TT $_{3}$

Bangla ST

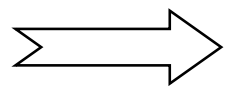

Translation in English

Bangla author

Translator

FICTION

FICTION

Thrice removed from ST Proper (triple distancing) 
This paper therefore proposes to ascribe significance to the loss of natural language of expression that the refugee had to undergo in the post-partition time frame due to the subtle politics of linguistic and cultural violence inflicted.

Remaining mentally anchored on 'Bengal's shore' forever and having been denied the moment of adequate articulation of this loss in factual terms ('fact' to be understood as connotative of expression in Bangal vis-à-vis Bangla), being victimized by the immediate trauma of the varied atrocities inflicted as well as the politics of state policy that attributed partition of Western India primordial signification, the Bengali Hindu refugee migrating from erstwhile East Pakistan (and now Bangladesh) to India, carrying his home 'in two carrier bags', to quote the lyrics of Roger Whitaker's ${ }^{\text {iii }}$ famous country number, has never 'really' spoken. The grand canon of conventional Indian literary historiography (read Indian English) has carried on with the same bias of signification probably because of the fact that Bengal in the post-independence and post-partition phase has undergone gradual erosion of national importance. Moreover, it has been time and again asserted by historians of conventional historiography that the partition and resultant exodus of Punjab was accomplished in one sweep (1947-50), whereas that of Bengal has been an ongoing process due to very porous borders. Very crude methods of comparative evaluation of the text of partition violence and resultant bloodshed have been employed in categorizing the partition of Punjab as more severe and brutal (Butalia, Bhalla etal). The state policies of rehabilitation of the refugees from the two sides have also not been impartial if not biased. All these had their influence on the construction of canonical literary historiography and the subsequent symbolic annihilation of the Bengal partition history and its documentation in literary history. Sadly, the first generation refugees themselves (the generation of our own grandparents) are fast becoming extinct and so is the repository of oral narratives of partition- the archives of shared social memory. What is heard, being far removed from the historical moment of rapture that was partition and with the loss of that fateful generation, is bound to be 'fiction' and not 'fact'. That historical moment of rupture known as the Partition of Bengal as well as the resources (human) of perception and documentation have thus been irretrievably lost due to these cumulative causes. This paper argues that any attempt at documenting the same now would lead to obvious fictionalization and fantasizing of the loss as is evident in original and translational post-independence, post-partition Indian English literaturethe moment of loss being the moment of fictional genesis.

This paper also argues and proposes the necessity of identifying two specific periods (beyond conventional pre- and post-independence markers) whose axiomatic point would be the partition of Eastern India/ undivided Bengal viz. pre- and post-partition Indian Literature. The same would apply to Indian English Literature both in original and in translation, which exhibits a strange yet wishful amnesia in this regard. The grand canonical construct of Indian English Literary historiography has attempted an erasure of the significance of this crucial landmark keeping it (esp. partition and the resultant refugee exodus in Eastern India) low key, whereas in the words of Tasleema Nasreen, the trauma of partition of Bengal has rendered the glory of 1947 in the refugee psyche dim, the jubilation of independence being eclipsed by the sorrow and trauma of the divide.

\section{Notes}

\footnotetext{
${ }^{\mathrm{i}}$ An Indian sparrow with brown body, white abdomen and yellow legs.

ii In 1959, Roman Jacobson, while dealing with the complexities of transferring linguistic andcultural elements in translation, stated that there are three modes of interpreting the verbal sign; 'it can be translated into other
} 
signs of the same language, into another language, or into another, nonverbal system of symbols'. He called the last inter-semiotic translation or transmutation.

iii Born in Nairobi to English parents on $27^{\text {th }}$ March, 1936, is a Kenyan-British singer, song writer and musician. His music is an eclectic mix of folk music and popular songs in addition to radio airplay hits. "Streets of London" from which this is taken, is a folk song written by Ralph McTell but popularised by Whitaker.

\section{REFERENCES:}

(Both in English and Bengali)

Bandopadhyay, Atin. (1986). Nilkantha Pakhir Khonje. Kolkata: Karuna Prakashani.

Bhalla, Alok. (1993). Stories about the Partition of India, 3 vols. Delhi: Indus/ Harper Collins.

Bhalla, Alok. (2006). Partition Dialogue: Memories of a Lost Home. Delhi: Oxford University Press.

Butalia, Urvashi. (1998). The Other Side of Silence: Voices from the Partition of India. Delhi: Viking.

Chakraborti, Basudeb. (2007). Indian Partition Fiction in English and in English Translation: A Text on HinduMuslim Relationship. Papyrus: Calcutta.

Chakraborty, Bidyut. (2004). The Partition of Bengal and Assam: Contours of Freedom. London: Routledge.

Chakraborty, Prafulla K. (1990). The Marginal Men. Kalyani: Lumiere Books.

Chatterjee, Partha. (1986). Nationalist Thought and the Colonial World: A Derivative Discourse. Delhi: Oxford University Press.

Chattopadhyay, Sakti, ed. (1970). Purba Banglar Shrestha Kabita, Kolkata: Aruna Prakashani.

Das, Dilip. (2000). Mastule Megher Pataka. 29-30, Agartala: Pounami Prakashan..

Das, Jibanananda.(1985). Jalpaihati. Jibanananda Samagra, vol 1, ed. Debesh Roy, Kolkata: Pratikshan.

Das, Jibanananda. (1993) Rupashi Bangla. Kolkata: Kabya Sangraha.

Dasgupta, Subhoranjan and Jasodhara Bagchi, eds, (2007). The Trauma and the Triumph: Gender and Partition in Eastern India. Kolkata: Stree

Elias, Akhtaruzzaman. (1996). Khowabnama. Kolkata: Naya Udyog.

Gangopadhyay, Sunil. (1971). Purba Paschim. Kolkata: Ananda Pub.

Gupta, Ashes. (2009)'Translation as an act of Ventriloquism: the Author-Translator- Hegemony', Translation Today (A biennial peer reviewed Journal), Vol.6 No.1 \& 2, p. 107-114, Mysore: CIIL.

Gupta, Ashes. (2012). 'Living the Dream: Narrating a Landscape Lost and a Land Left Behind', Barbed Wire ed. Jayita Sengupta, p.50-65.New Delhi: Routledge.

Jakobson, Roman. (1971). Selected Writings II: Word and Language. The Hague: Mouton.

Jakobson, Roman. (1959). On linguistic aspects of translation. The Translation Studies Reader, ed. Lawrence Venuti, 138-143. New York and London: Routledge.

Nasreen, Taslima. (1993). Phera. Kolkata: Ananda Pub.

Nasreen, Taslima., (1994). 'Asvikar'. Ay Kasto Jhenpe Jibon Debo Mepe. Dhaka: Gyankosh Prakashani.

Snell-Hornby, Mary. (2006) The Turns of Translation Studies : New paradigms or shifting viewpoints? Amsterdam/Philadelphia: John Benjamins..

Spivak, Gayatri Chakravorty. (1988). 'Can the subaltern Speak?' in Cary Nelson and Lawrence Grossberg (eds.) Marxism and the Interpretation of Culture. 271-313, Arbana: Univ. of Illinois Press. 